Supporting information for

\title{
Antiviral Agents from Multivalent Presentation of Sialyl Oligosaccharides on Brush Polymers
}

Shengchang Tang, ${ }^{\dagger}$ Wendy B. Puryear, ${ }^{\ddagger}$, Brian M. Seifried, ${ }^{\dagger}$ Xuehui Dong, ${ }^{\dagger}$ Jonathan A. Runstadler, ${ }^{\ddagger}{ }^{\S}$ Katharina Ribbeck, ${ }^{\star}$ and Bradley D. Olsen ${ }^{*}$,

Department of Chemical Engineering, ${ }^{\dagger}$ Department of Biological Engineering, ${ }^{\star}$ and Division of Comparative Medicine, ${ }^{\S} 77$ Massachusetts Avenue, Cambridge, MA 02139, USA

*To whom correspondence should be addressed: B.D.O. (Email: bdolsen@mit.edu) 
Table of Contents

S1. Supplementary Figures Cited in the Main Text $\quad 2$

$\begin{array}{ll}\text { S2. Materials } & 5\end{array}$

S3. Instrumentation and Characterization $\quad 5$

S4. General Procedures for Ring-Opening Metathesis Polymerization 6

$\begin{array}{ll}\text { S5. Hemagglutination Inhibition Assay } & 7\end{array}$

$\begin{array}{ll}\text { S6. In Vitro Infection Assay } & 7\end{array}$

$\begin{array}{ll}\text { S7. Acidic Ninhydrin Assay } & 7\end{array}$

$\begin{array}{lr}\text { S8. Synthetic Procedures for Macromonomers } & 8\end{array}$

S9. Additional Supporting Figures $\quad 11$
a. GPC
b. NMR
c. MALDI-TOF MS

S10. References

16 


\section{S1. Supplementary Figures Cited in the Main Text}

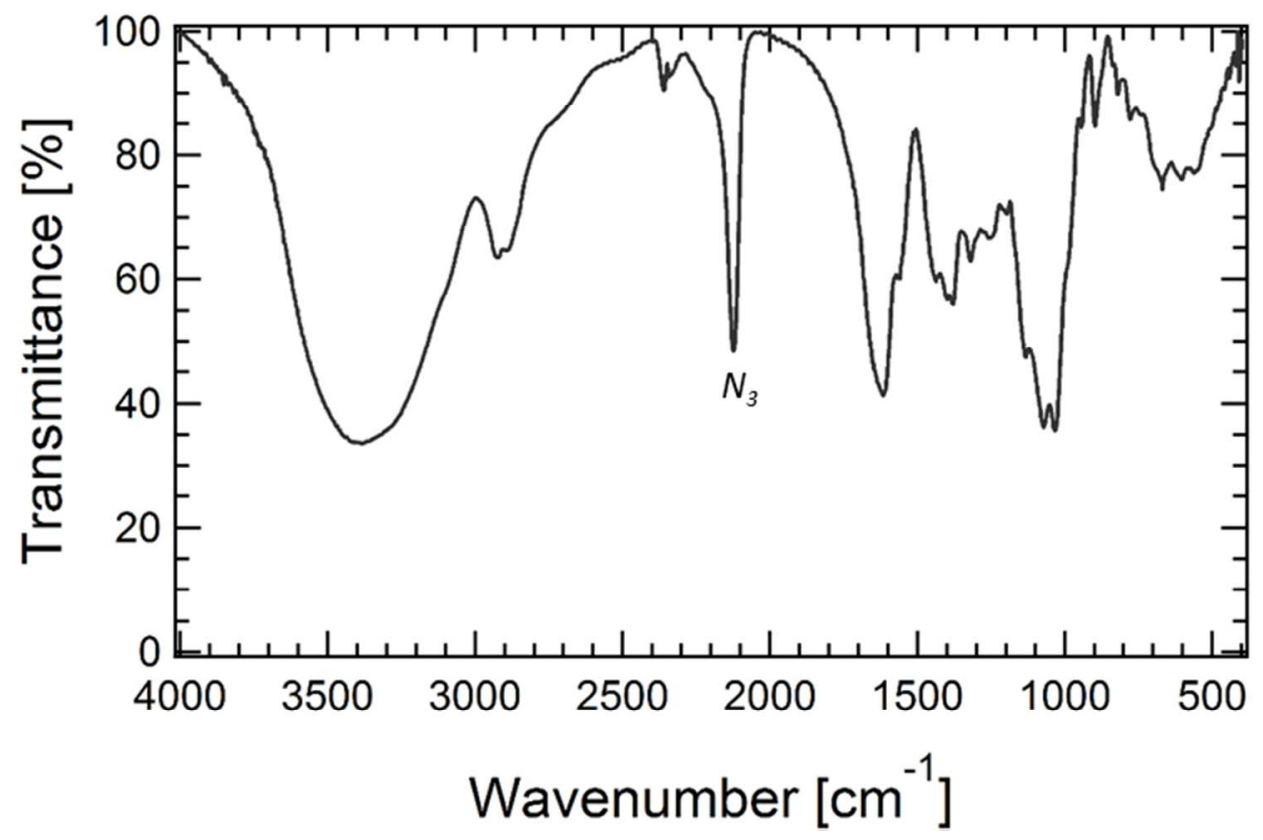

Figure S1. FTIR spectrum of 6'-sialyllactose azide. The peak at $2123 \mathrm{~cm}^{-1}$ corresponds to the antisymmetric stretch of azide.

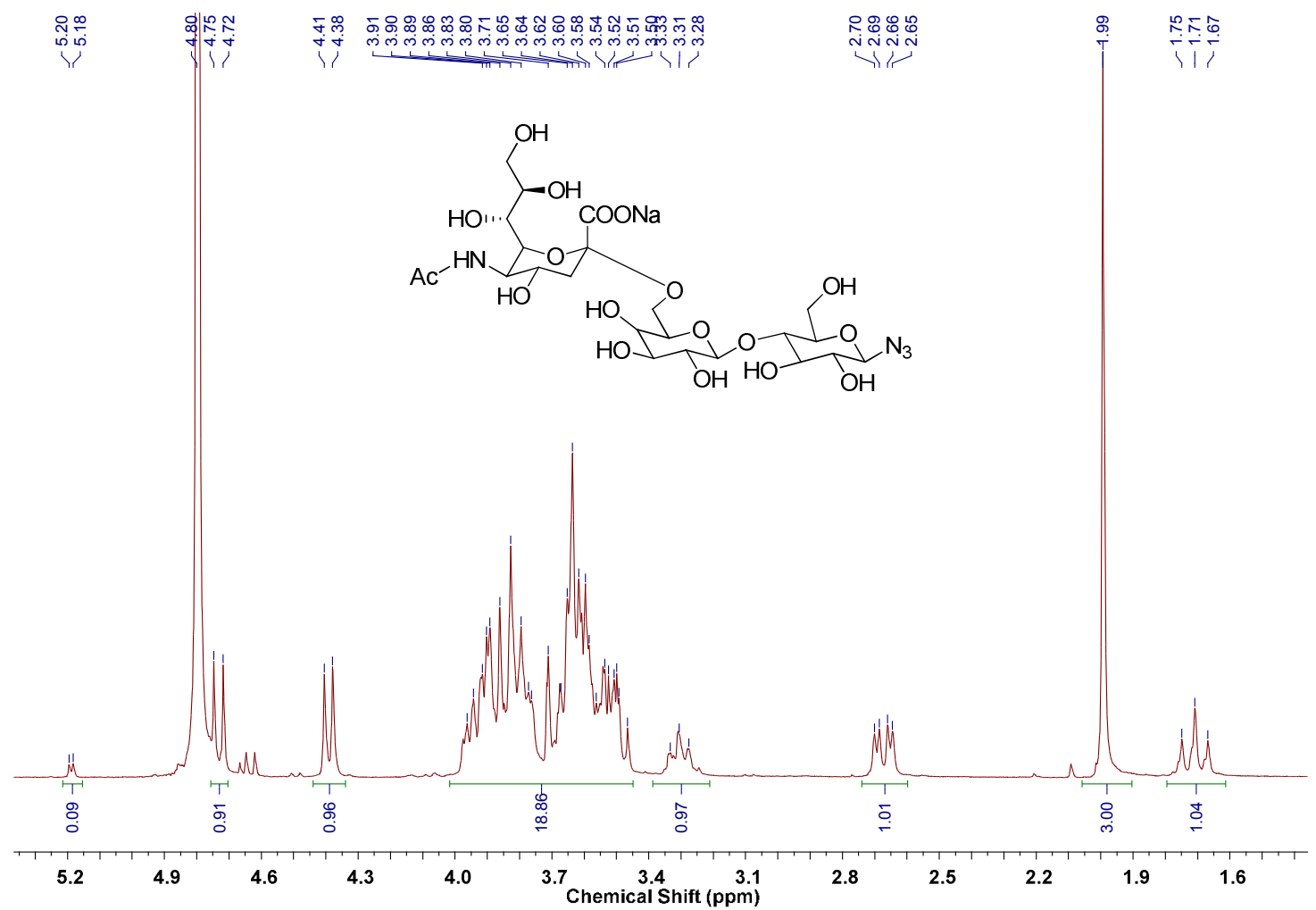

Figure S2. ${ }^{1} \mathrm{H}$ NMR spectrum of 6 '-Sialyllactose azide in $\mathrm{D}_{2} \mathrm{O}(300 \mathrm{MHz})$. 


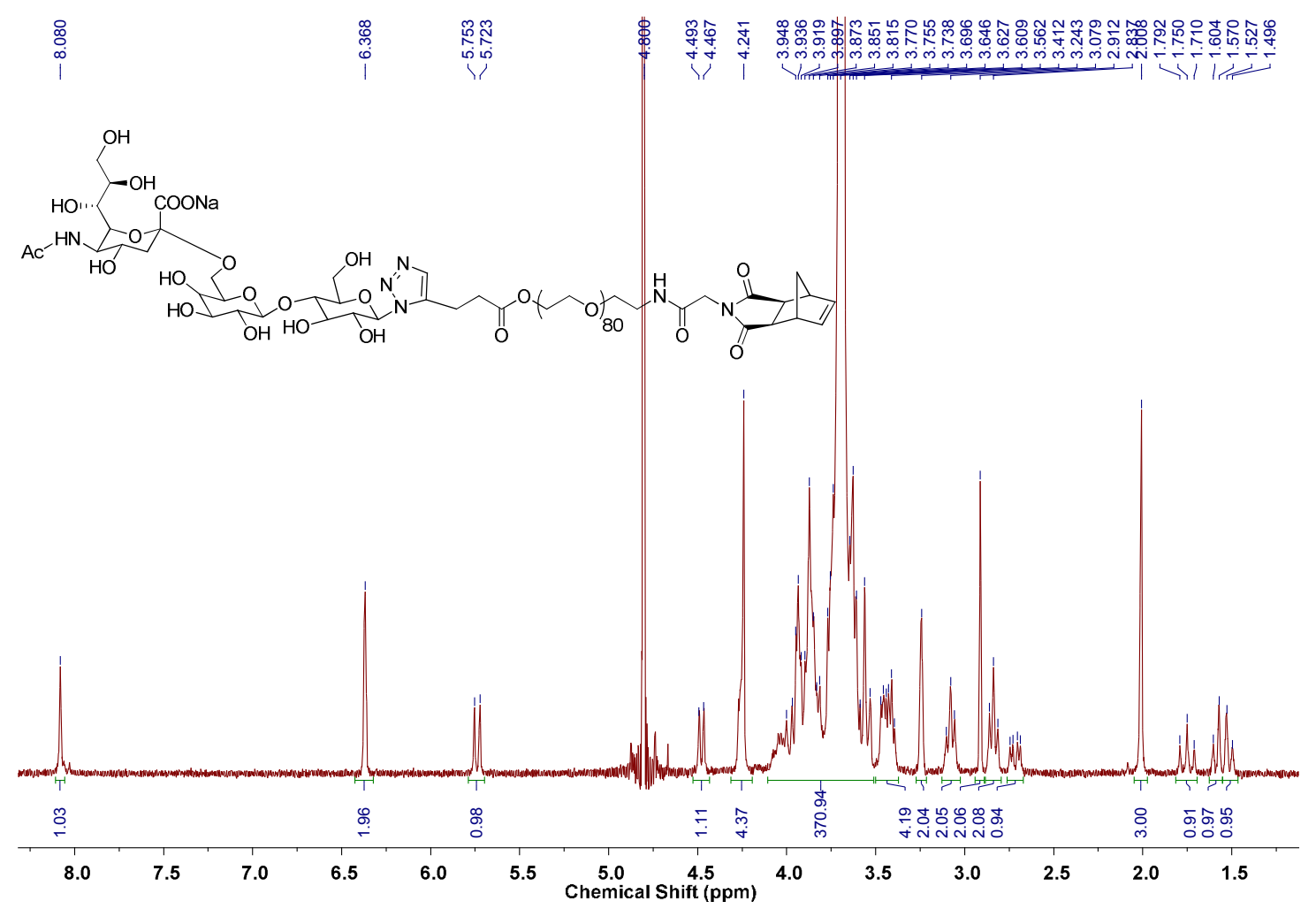

Figure S3. ${ }^{1} \mathrm{H}$ NMR spectrum of NB-PEG-SA in $\mathrm{D}_{2} \mathrm{O}(300 \mathrm{MHz})$.

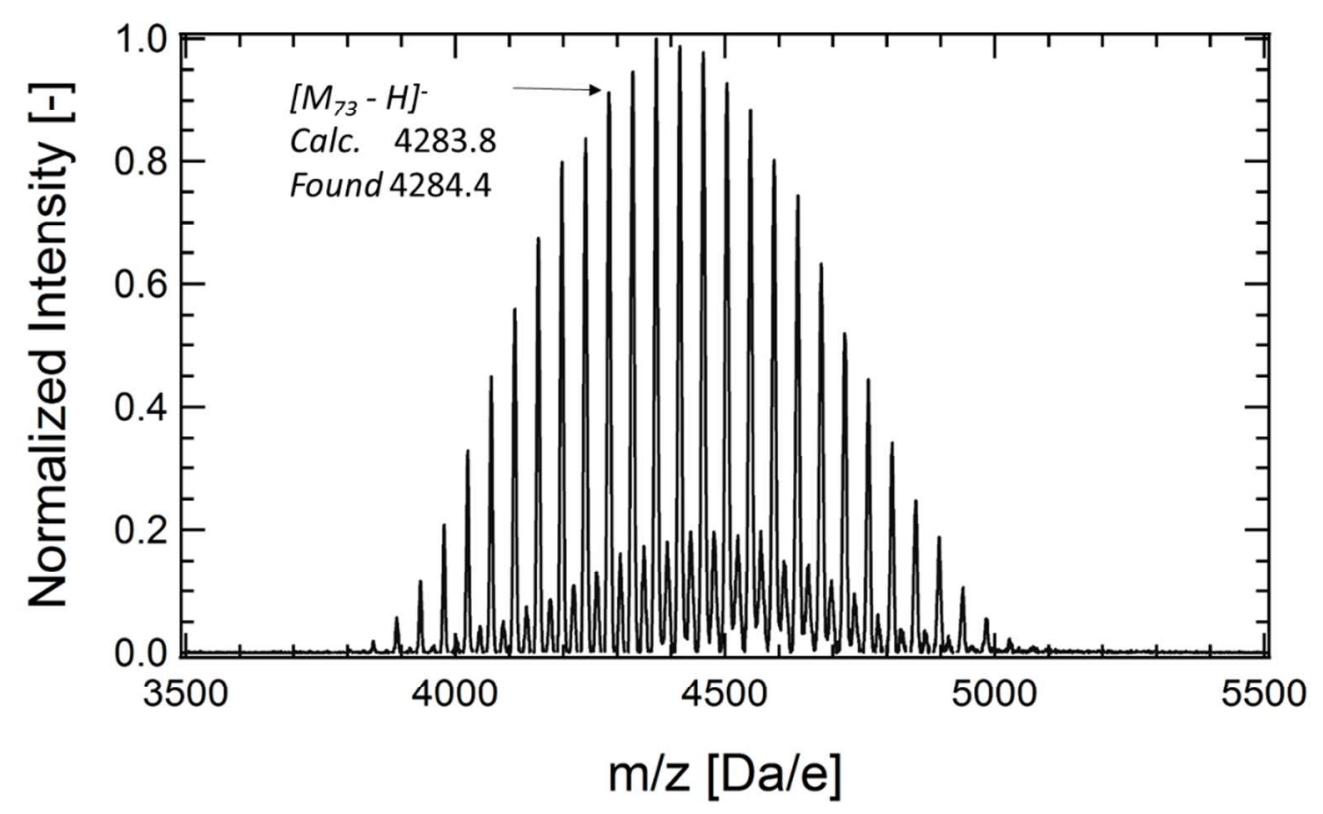

Figure S4. MALDI-TOF MS of NB-PEG-SA (negative linear mode). 


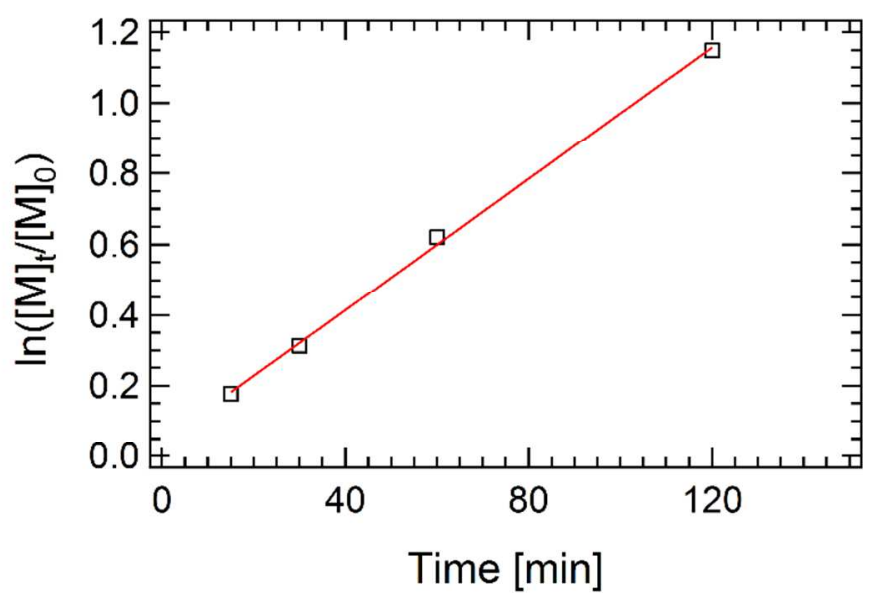

Figure S5. Representative kinetics in ROMP showing linear chain growth. Polymerization condition: $[\mathrm{MM}]=0.025 \mathrm{M}$, target $\mathrm{DP}=50$. The propagation rate constant was determined from the slope, which gives $k_{p}=0.0093 \mathrm{~min}^{-1}$.

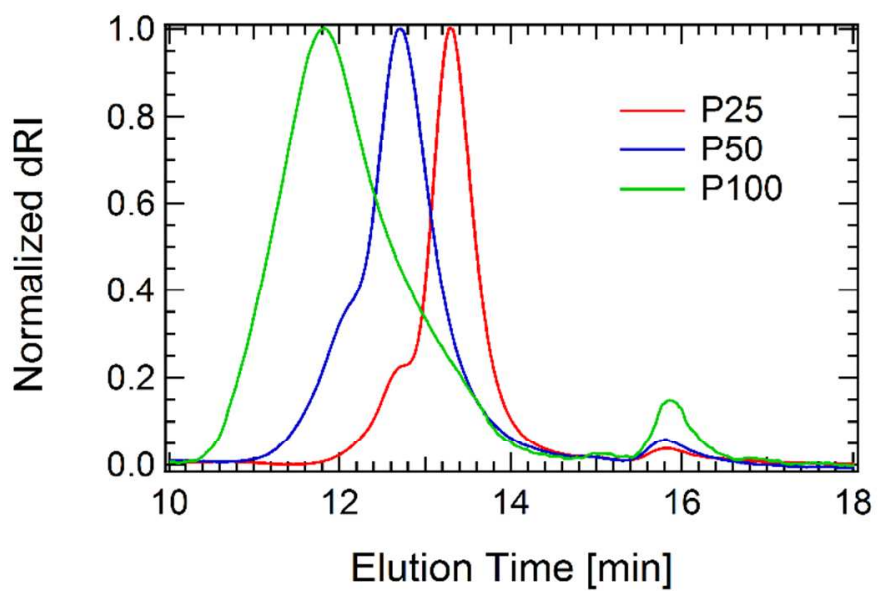

Figure S6. GPC traces of brush homopolymers P25, P50 and P100 (crude polymerization mixture). The peaks appearing at ca. 16 min were from residual MMs.

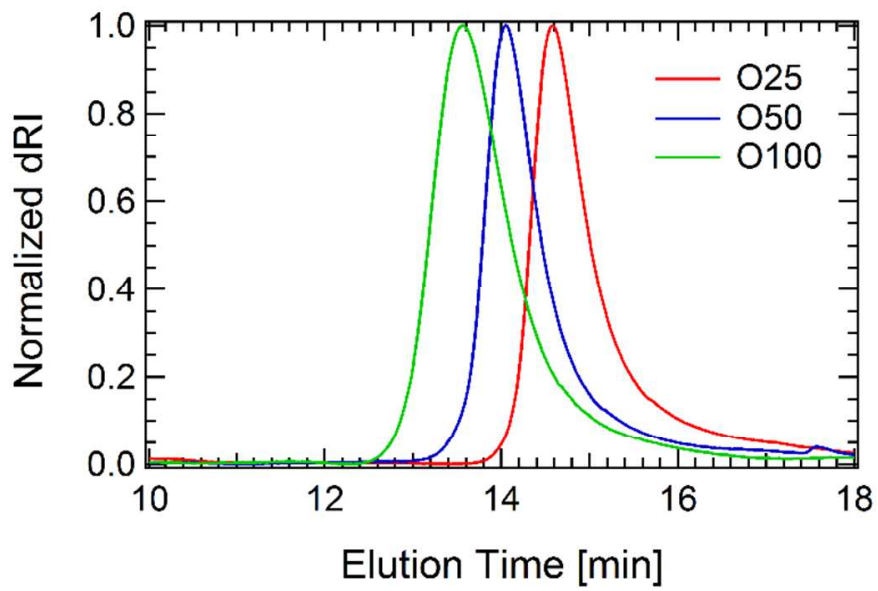

Figure S7. GPC traces of brush polymers O25, O50 and O100 (crude polymerization mixture). 


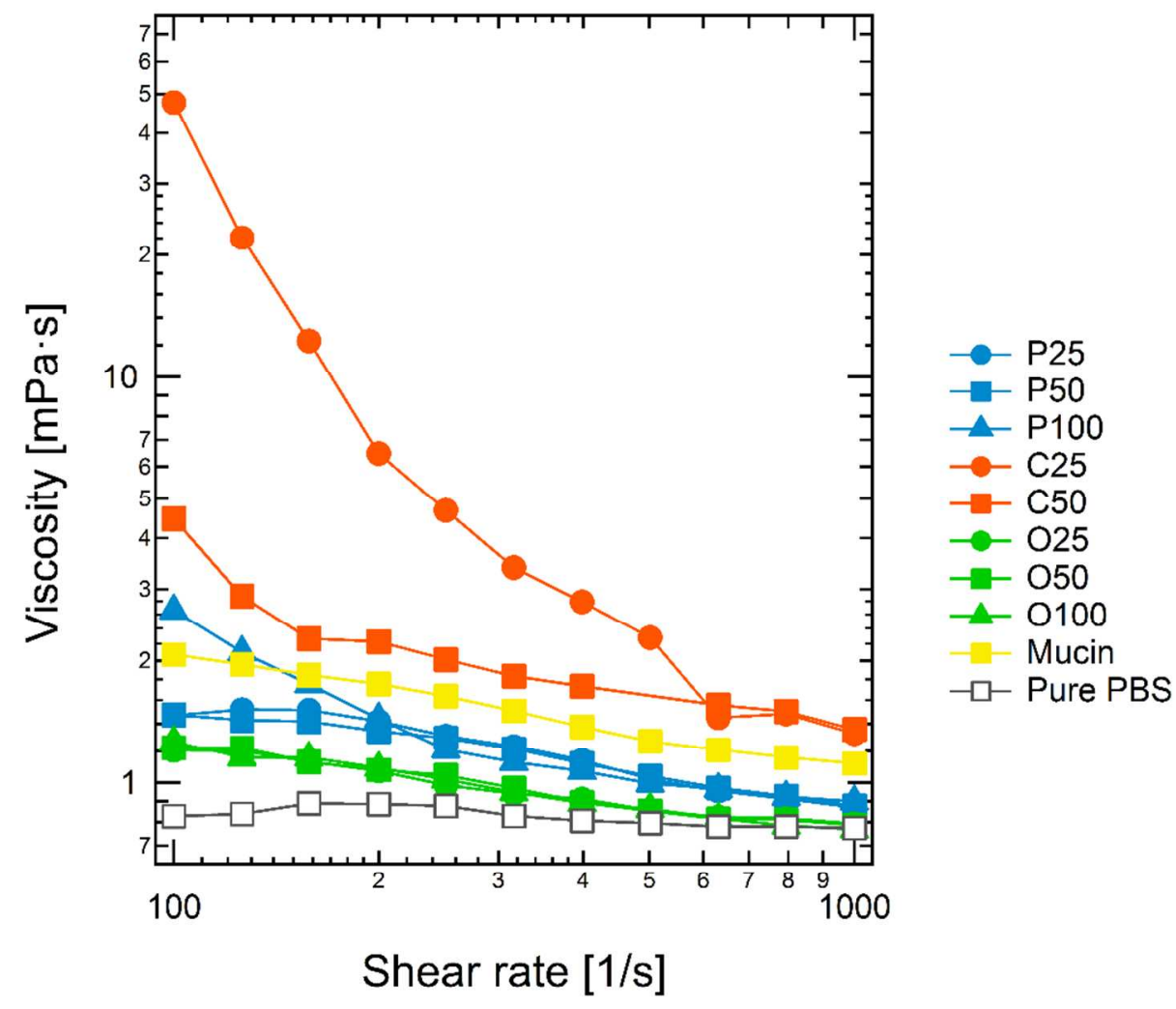

Figure S8. Viscosity measurement of brush polymer solutions at $37{ }^{\circ} \mathrm{C}$. The sialic acid concentration in all solutions was $0.5 \mathrm{mM}$; therefore, $\mathrm{C} 25$ and C50 polymers are at higher concentration and therefore have higher viscosities due to the lower density of sialic acid on these brushes.

\section{S2. Materials}

Hydroxyl poly(ethylene glycol) amine, $\mathrm{HCl}$ salt $\left(M_{n}=3500 \mathrm{~kg} / \mathrm{mol}, Ð=1.03\right)$ was purchased from JenKem Technology USA. Tris[(1-benzyl-1H-1,2,3-triazol-4-yl)methyl]amine (TBTA) was purchased from Click Chemistry Tools. 6'-sialyllactose sodium salt was purchased from Carbosynth Limited. Mucin from the bovine submaxillary gland was purchased from Millipore (Cat\# 499643, Lot\# D00160765). While there are always concerns that the purification procedures for mucins may change their form from the native structure, the purification procedure for submaxillary gland mucins has been demonstrated to preserve both the high-molecular-weight structure and the sialic acid content of the original molecules. ${ }^{1,2}$

Compounds cis-5-norbornene-exo-2,3-dicarboxylic anhydride ${ }^{3}, \quad N$-(glycine)-cis-5-norbornene-exodicarboximide ${ }^{4}$, catalyst $\mathrm{G} 3\left(\mathrm{H}_{2} \mathrm{IMes}\right)(\mathrm{pyr})_{2}(\mathrm{Cl})_{2} \mathrm{Ru}=\mathrm{CHPh}^{5}$, were prepared according to published procedures.

All other chemical reagents were purchased from commercial sources (Sigma-Aldrich and VWR) and used as received unless otherwise noted.

\section{S3. Instrumentation and Characterization}

NMR spectra were recorded on a Mercury $300 \mathrm{MHz}$ spectrometer or an INOVA $500 \mathrm{MHz}$ spectrometer. The residual undeuterated solvent peaks were used for references. The following abbreviations are used 
to denote the multiplicities: $\mathrm{s}=$ singlet, $\mathrm{d}=$ doublet, $\mathrm{t}=$ triplet, $\mathrm{q}=$ quartet, $\mathrm{m}=$ multiplet, $\mathrm{br}=$ broad. Coupling constants $J$ are reported in Hertz (Hz).

Gel permeation chromatography (GPC) measurements were performed on an Agilent 1260 LC system with two columns (ResiPore, $300 \times 7.5 \mathrm{~mm}$, Agilent Technologies, CA) in series at $70{ }^{\circ} \mathrm{C}$ and a flow rate of $1 \mathrm{~mL} / \mathrm{min}$, where DMF with $0.02 \mathrm{M} \mathrm{LiBr}$ was used as the mobile phase. The molecular weights were determined using a Wyatt miniDAWN TREOS multi-angle light scattering detector and a Wyatt Optilab T-rEX differential refractive index detector.

Matrix-assisted laser desorption/ionization time-of- flight (MALDI-TOF) mass spectra were obtained on a Bruker Microflex instrument equipped with a $337 \mathrm{~nm}$ nitrogen laser in Koch Institute at MIT. $\alpha$-Cyano4-hydroxycinnamic acid (CHCA) was used as matrix. Low resolution mass spectra (LRMS) of small molecules were obtained from liquid chromatrography-mass spectrometry (LC-MS) analysis using an Agilent 6130 quadrupole mass spectrometer.

High performance liquid chromatography (HPLC) purification was performed on an Agilent 1260 system with a Zorbax 300SB-C18 PrepHT column. The mobile phase was a mixture of $0.1 \%$ acetic acid in MilliQ water and HPLC-grade acetonitrile.

Fourier transform infrared (FTIR) measurements were performed on a Thermo Nexus 870 spectrometer and results were processed using OMNIC software.

Ultraviolet-visible (UV-vis) absorbance scans were obtained on a Tecan Infinite 200 Pro microplate reader at $1 \mathrm{~nm}$ resolution.

Viscosity measurements were performed on an Anton Paar MCR 702 rheometer operated at the singledrive mode with a cone-and-plate geometry ( $50 \mathrm{~mm}$ diameter, $0.5^{\circ}$ cone angle and $50 \mu \mathrm{m}$ truncation gap). The temperature was controlled by a Peltier plate and was kept constant at $37^{\circ} \mathrm{C}$. Water evaporation was minimized by adding deionized water on top of the cone. Shear viscosities were determined in the shear rate range of $100-1000$ 1/s.

Fluorescence microscopy images were acquired at 10× magnification at the A488 channel on an Olympus IX-81 inverted fluorescence microscope. The exposure time was fixed at $250 \mathrm{~ms}$ for consistency.

\section{S4. General Procedures for Ring Opening Metathesis Polymerization (ROMP)}

All polymerizations were performed in degassed DMF (HPLC grade) under nitrogen atmosphere in a glovebox. A stock solution of G3 catalyst was freshly prepared at a concentration of $4 \mathrm{mg} / \mathrm{mL}$. In a typical experiment, a $2 \mathrm{~mL}$ vial equipped with a small stir bar was charged with $100 \mu \mathrm{L}$ of MM solution. Under vigorous stirring, the desired amount of catalyst solution was added to the vial to initiate polymerization. The final concentration of MMs was adjusted from 0.01 to $0.05 \mathrm{M}$ such that the gelation was retarded during polymerization to enhance kinetic control. The reaction time was varied from 2 to 24 $\mathrm{h}$ to maximize the conversion of MMs, and the reaction was terminated by addition of $1-2$ drops of cold ethyl vinyl ether. The solution was then diluted and a small aliquot was taken for GPC analysis.

Polymers were diluted with $14 \mathrm{~mL}$ of MilliQ water and transferred to a $15 \mathrm{~mL}$ centrifugal filter (50 $\mathrm{kDa}$ MWCO for entries 1-5 in Table 1, and $10 \mathrm{kDa}$ MWCO for entries 6-8 in Table 1). The solution was concentrated to less than $1 \mathrm{~mL}$ by spinning at 4,000 RPM at room temperature. The remaining solution was again diluted with $14 \mathrm{~mL}$ of water. After the process was repeated $5-10$ times to ensure complete removal of unreacted MMs, the remaining solution was lyophilized to afford pure brush polymers for subsequent studies. 


\section{S5. Hemagglutination Inhibition Assay}

In a typical experiment, $25 \mu \mathrm{L}$ of virus suspension containing 4 hemagglutinin units (HAU) was added to the first column of a 96-well V-bottom plate and was serially diluted to the columns after. Then $25 \mu \mathrm{L}$ of polymer solution $([\mathrm{SA}]=0.5 \mathrm{mM})$ in Dulbecco's phosphate buffered saline (DPBS without $\mathrm{Ca} 2+$ and $\mathrm{Mg} 2+$, Lonza BioWhittaker ${ }^{\mathrm{TM}}$ ) was added to each well. After the mixture was incubated at room temperature for $30 \mathrm{~min}, 50 \mu \mathrm{L}$ of $0.5 \%$ chicken erythrocytes was added to each well. The entire plate was gently tapped to ensure good mixing of the components, and the results were reported after $1 \mathrm{~h}$ incubation at room temperature. Incomplete hemagglutination could be identified by a teardrop pattern when the well plate was tilted. The titer was determined from the maximum dilution that still showed complete hemagglutination inhibition.

\section{S6. In Vitro Infection Assay}

The in vitro infection assays were performed using a procedure slightly modified from a previous report.3 MDCK-SIAT1-CMV-PB1 cells were cultured in D10 medium to reach $80-100 \%$ confluency, trypsinized, resuspended and diluted to 300,000 cells $/ \mathrm{mL}$. In the infection experiments, 30,000 cells were seeded in each well of a 96-well flat bottom plate (tissue-culture treated) and were allowed to adhere to the plate at $37^{\circ} \mathrm{C}$ overnight $(16-18 \mathrm{~h})$. Medium was then removed and replaced by $150 \mu \mathrm{L}$ of infection growth medium (IGM). After incubation at $37^{\circ} \mathrm{C}$ for $3 \mathrm{~h}$, the medium was removed and replaced by 50 $\mu \mathrm{L}$ of polymer solution at various concentrations in DPBS. After incubation at $37{ }^{\circ} \mathrm{C}$ for $2 \mathrm{~h}, 5 \mu \mathrm{L}$ of engineered A/WSN/1933 (H1N1) virus with PB1-GFP reporter genes $\left(1 \times 10^{7}\right.$ virus particles $\left./ \mathrm{mL}\right)$ was gently added to each well. For the negative control, $5 \mu \mathrm{L}$ of DPBS was added. Solutions were removed after another $2 \mathrm{~h}$ incubation step, and cells were washed with $150 \mu \mathrm{L}$ DPBS three times. After $150 \mu \mathrm{L}$ of IGM was added to each well, cells were cultured at $37^{\circ} \mathrm{C}$ for $18 \mathrm{~h}$ to allow expression of GFP. The number of GFP positive cells was counted with an Accuri C6 flow cytometer. Results were analyzed using the FlowJo software and 0.5\% GFP-positive cells was set for the uninfected control.

Media used in the studies was prepared according to the recipes shown below. Solutions were filtered through a $0.22 \mu \mathrm{m}$ PES filter and stored at $4{ }^{\circ} \mathrm{C}$.

(1) D10 medium: DMEM (HyCloneTM, \#SH30243.01) supplemented with 10\% heat-inactivated fetal bovine serum (FBS), $100 \mathrm{U} / \mathrm{ml}$ penicillin and $100 \mathrm{ug} / \mathrm{ml}$ streptomycin.

(2) IGM: OptiMEM (InvitrogenTM, \#31985-088) supplemented with 0.01\% FBS (heat-inactivated), 0.3\% BSA (InvitrogenTM, \#15260-037), $100 \mathrm{U} / \mathrm{ml}$ penicillin and $100 \mu \mathrm{g} / \mathrm{ml}$ streptomycin, and $100 \mu \mathrm{g} / \mathrm{ml}$ calcium chloride.

\section{S7. Acidic Ninhydrin Assay}

To determine SA content in the commerically available mucin sample, a published procedure ${ }^{6}$ was adopted with slight modification. Acid ninhydrin reagent was prepared by stirring $1 \mathrm{~g}$ of ninhydrin in 24 $\mathrm{mL}$ of glacial acetic acid until the ninhydrin was completely dissolved. Then, $16 \mathrm{~mL}$ of concentrated $\mathrm{HCl}$ (ca. 36\%) was slowly added to the mixture. In a typical assay setup, mucin solutions, acid ninhydrin reagent and glacial acetic acid were mixed at a 1:1:1 volume ratio. The mixture was boiled for exactly 10 min on a heat block and was cooled down immediately in a chilled water bath. Subsequently, $100 \mu \mathrm{L}$ of the reaction mixture was added to a Greiner UV-Star ${ }^{\circledR} 96$ well plate (flat bottom), and an absorbance scan was taken from $350 \mathrm{~nm}$ to $700 \mathrm{~nm}$. The absorbance at $470 \mathrm{~nm}$ was used to quantify the sialic acid content. Experiments were performed in triplicates. The sialic acid content was determined to be ca. 10 $\mathrm{wt} \%$ in mucins. 


\section{S8. Synthetic Procedures for Macromonomers}

\section{Synthesis of NB-NHS}

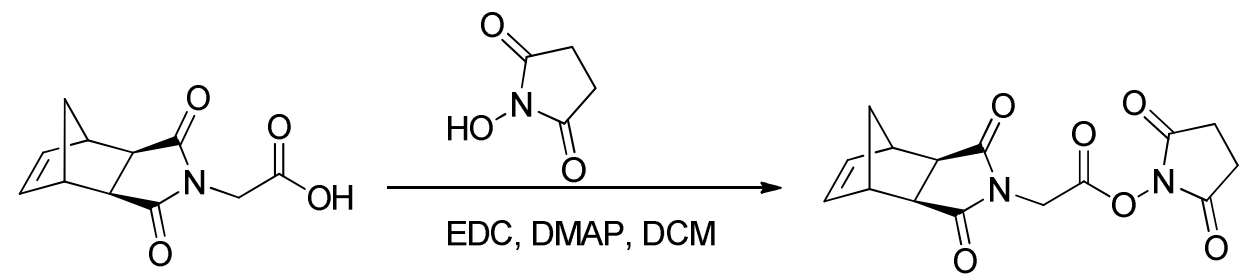

To a $300 \mathrm{~mL}$ round bottom flask was added $N$-(glycine)-cis-5-norbornene-exo-dicarboximide (500 $\mathrm{mg}$, $2.26 \mathrm{mmol}$ ), $N$-(3-Dimethylaminopropyl)- $N$ '-ethylcarbodiimide hydrochloride (EDC·HCl, $650 \mathrm{mg}, 3.39$ $\mathrm{mmol}$ ), and 4-(dimethylamino)pyridine (DMAP, $41.4 \mathrm{mg}, 0.34 \mathrm{mmol})$. Dichloromethane (100 $\mathrm{mL})$ was then added to dissolve the solids. After 15 minutes, $N$-hydroxy succinimide (390 $\mathrm{mg}, 3.39 \mathrm{mmol}$ ) was added, and the reaction was stirred at room temperature overnight. Solvent was removed under vacuum, and the residue was purified by silica gel flash column chromatography using $50-80 \%$ EtOAc in hexanes to give white solids (319.4 $\mathrm{mg}$, $44 \%$ yields, $R_{f}=0.2,50 \%$ EtOAc in hexanes).

${ }^{1} \mathrm{H}$ NMR (300 MHz, $\mathrm{CDCl}_{3}$ ): $\delta 6.27(\mathrm{~s}, 2 \mathrm{H}), 4.53(\mathrm{~s}, 2 \mathrm{H}), 3.28(\mathrm{~s}, 2 \mathrm{H}), 2.81(\mathrm{~s}, 4 \mathrm{H}), 2.75(\mathrm{~s}, 2 \mathrm{H}), 1.53-$ $1.44(\mathrm{~m}, 2 \mathrm{H})$.

LRMS (ESI) $\mathrm{m} / \mathrm{z}$ calculated for $\mathrm{C}_{15} \mathrm{H}_{15} \mathrm{~N}_{2} \mathrm{O}_{6}[\mathrm{M}+\mathrm{H}]^{+}$319.1, found 319.0.

Synthesis of NB-PEG-OH<smiles>O=C(CN1C(=O)[C@H]2C3C=CC(C3)[C@H]2C1=O)ON1C(=O)CCC1=O</smiles>
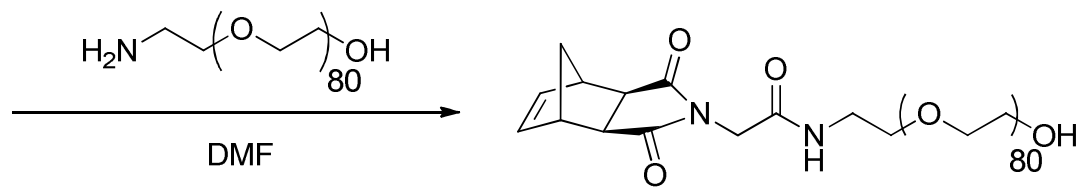

Hydroxyl PEG amine $(1 \mathrm{~g})$ was dissolved in $100 \mathrm{~mL}$ of $1 \mathrm{M}$ sodium carbonate solution and stirred for 30 min to liberate the free amine. The aqueous solution was extracted by dichloromethane $(3 \times 50 \mathrm{~mL})$. The combined organic phase was dried over $\mathrm{Na}_{2} \mathrm{SO}_{4}$, and the solvent was removed under vacuum to afford $0.96 \mathrm{~g}$ white solid (yield 96\%).

Purified hydroxyl PEG amine was dissolved in anhydrous N,N-dimethylformamide (DMF, $30 \mathrm{~mL}$ ), and NB-NHS ester $(109.4 \mathrm{mg}, 0.34 \mathrm{mmol})$ was added in one portion. After reaction overnight, solvent was removed under vacuum, and the residue was redissolved in a small amount of dichloromethane (ca. 10 $\mathrm{mL}$ ) and precipitated in cold diethylether. The precipitation was performed three times to give a white solid (0.98 g, yield 93\%).

${ }^{1} \mathrm{H}$ NMR (500 MHz, $\left.\mathrm{D}_{2} \mathrm{O}\right): 6.35(\mathrm{t}, 2 \mathrm{H}, J=2.0 \mathrm{~Hz}), 4.22(\mathrm{~s}, 2 \mathrm{H}), 3.82(\mathrm{t}, 2 \mathrm{H}, J=4.5 \mathrm{~Hz}), 3.73-3.58(\mathrm{~m}$, $384 \mathrm{H}), 3.53$ (m, 2H, $J=4.5 \mathrm{~Hz}), 3.39$ (t, 2H, $J=5.0 \mathrm{~Hz}), 3.23$ (s, 2H, $J=1.5 \mathrm{~Hz}), 2.89$ (s, 2H), 1.57 (d, $1 \mathrm{H}, J=10.0 \mathrm{~Hz}), 1.50(\mathrm{dt}, 1 \mathrm{H}, J=1.5 \mathrm{~Hz}$ and $10.0 \mathrm{~Hz})$.

The structure was also confirmed by MALDI-TOF MS (Figure S16).

Synthesis of NB-PEG-alkyne 

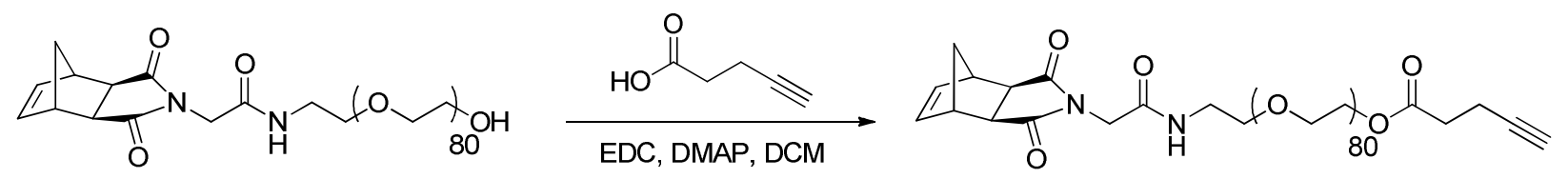

NB-PEG-OH (300 mg, $81 \mu \mathrm{mol})$, pentynoic acid (11.9 mg, $122 \mu \mathrm{mol})$, DMAP (2.0 mg, $16 \mu \mathrm{mol})$ were dissolved in $10 \mathrm{~mL}$ of dichloromethane. $\mathrm{EDC} \cdot \mathrm{HCl}(23.3 \mathrm{mg}, 122 \mu \mathrm{mol})$ was then added to the solution, and the reaction was stirred at room temperature overnight. After solvent was evaporated under vacuum, the crude product was dissolved in a small amount of dichloromethane and precipitated in cold diethylether. The precipitation was performed three times to give a white solid (290 mg, yield 94\%).

${ }^{1} \mathrm{H}$ NMR $\left(500 \mathrm{MHz}, \mathrm{CDCl}_{3}\right): \delta 6.76(\mathrm{~s}, 1 \mathrm{H}), 6.26(\mathrm{~s}, 2 \mathrm{H}), 4.26(\mathrm{t}, 2 \mathrm{H}, J=5.0 \mathrm{~Hz}), 4.15(\mathrm{~s}, 2 \mathrm{H}), 3.78(\mathrm{t}$, $2 \mathrm{H}, J=5.0 \mathrm{~Hz}), 3.72-3.54(\mathrm{~m}, 384 \mathrm{H}), 3.49$ (t, $2 \mathrm{H}, J=5.0 \mathrm{~Hz}), 3.45(\mathrm{~m}, 2 \mathrm{H}), 3.30(\mathrm{~s}, 2 \mathrm{H}), 2.72(\mathrm{~s}, 2 \mathrm{H})$, $2.58(\mathrm{~m}, 2 \mathrm{H}), 2.50(\mathrm{~m}, 2 \mathrm{H}), 1.98(\mathrm{t}, 1 \mathrm{H}, J=2.5 \mathrm{~Hz}), 1.87(\mathrm{~d}, 1 \mathrm{H}, J=10.0 \mathrm{~Hz}), 1.51(\mathrm{~d}, 1 \mathrm{H}, J=10.0 \mathrm{~Hz})$.

$\underline{\text { Synthesis of 6'-sialyllactose azide }}$

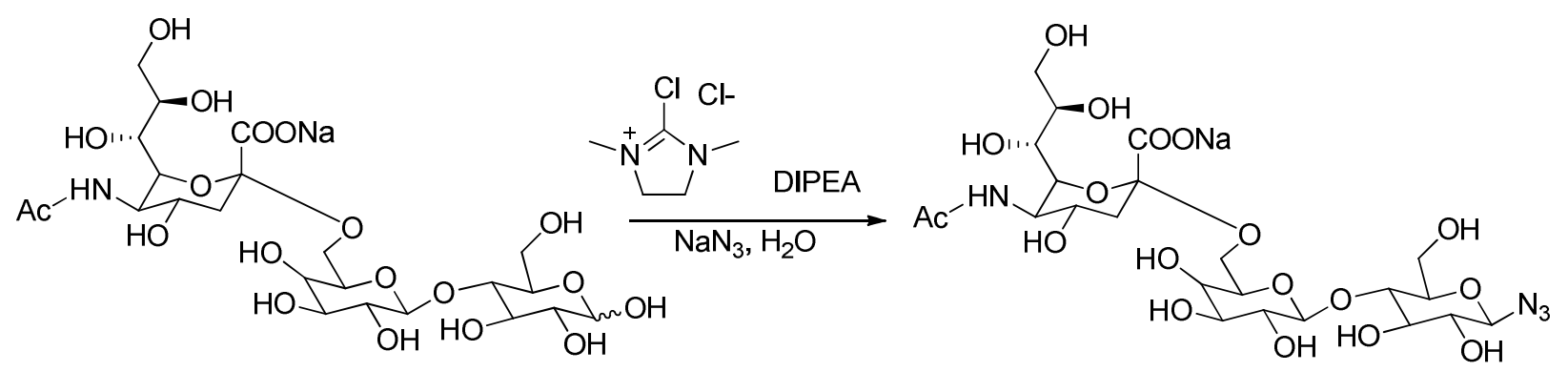

The synthetic procedure was slightly modified from the published literature. ${ }^{7-9}$ First, $N, N$ diisopropylethylamine (DIPEA, $1.33 \mathrm{~mL}, 7.63 \mathrm{mmol}$ ) was added to a clear solution containing 6'sialyllactose sodium salt $(500 \mathrm{mg}, 0.76 \mathrm{mmol})$ and sodium azide $(496 \mathrm{mg}, 7.63 \mathrm{mmol})$ in $1.57 \mathrm{~mL}$ of water. After 2-chloro-1,3-dimethylimidazolinium (DMC, $387 \mathrm{mg}, 2.29 \mathrm{mmol}$ ) was added, the two phase mixture was stirred vigorously at $0{ }^{\circ} \mathrm{C}$ for $1 \mathrm{~h}$. The solvent was then evaporated under vacuum, and DMF was added to dissolve the residual solid. Undissolved sodium azide was filtered, and the filtrated was concentrated under vacuum. The residual was dissolved in $50 \mathrm{~mL}$ of water and extracted with DCM (50 $\mathrm{mL} \times 2)$. The aqueous phase was loaded onto a short ion-exchange column packed with Amberlite IR120 resin (hydrogen form, previously activated with $1 \mathrm{M} \mathrm{NaOH}$ aqueous solution), and eluted with MilliQ water. The solution was neutralized to $\mathrm{pH} 6.5$, concentrated under vacuum, dialyzed against water (MWCO $500 \mathrm{Da}$ ), and lyophilized to give a white powder (413 mg, yield 80\%).

${ }^{1} \mathrm{H}$ NMR $\left(300 \mathrm{MHz}, \mathrm{D}_{2} \mathrm{O}\right): \delta 5.19(\mathrm{~d}, 0.09 \mathrm{H}, J=3.6 \mathrm{~Hz}), 4.74(\mathrm{~d}, 0.91 \mathrm{H}, J=8.7 \mathrm{~Hz}), 4.39(\mathrm{~d}, 1 \mathrm{H}, J=7.8$ $\mathrm{Hz}), 4.00-3.43(\mathrm{~m}, 18 \mathrm{H}), 3.31(\mathrm{t}, 1 \mathrm{H}, J=8.7 \mathrm{~Hz}), 2.67(\mathrm{dd}, 1 \mathrm{H}, J=4.5 \mathrm{~Hz}$ and $12.3 \mathrm{~Hz}), 1.99(\mathrm{~s}, 3 \mathrm{H})$, $1.71(\mathrm{t}, 1 \mathrm{H}, J=12.3 \mathrm{~Hz})$. The spectrum is similar to reference ${ }^{9}$, and $90 \%$ of the product is $\beta$ anomer.

LRMS (ESI) $\mathrm{m} / \mathrm{z}$ calculated for $\mathrm{C}_{23} \mathrm{H}_{37} \mathrm{~N}_{4} \mathrm{O}_{8}[\mathrm{M}-\mathrm{Na}]^{-}$657.2, found 657.2. 


\section{Synthesis of NB-PEG-SA}

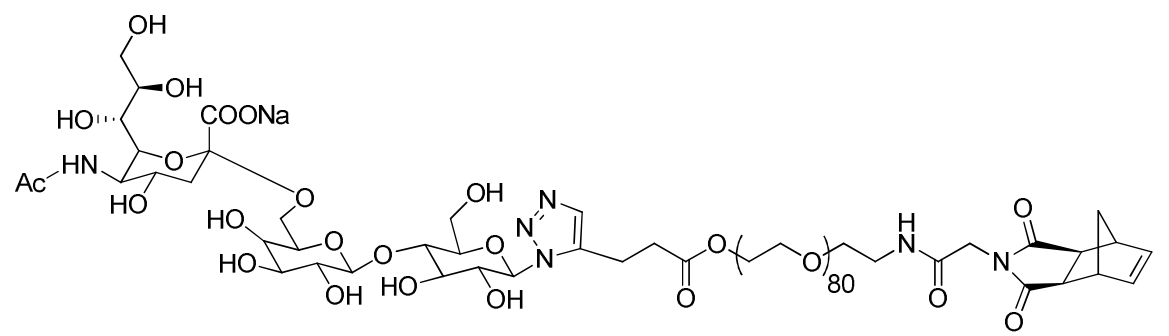

TBTA stock solution was prepared in DMF at a concentration of $88.7 \mathrm{mg} / \mathrm{mL}$, and $\mathrm{CuSO}_{4}$ stock solution was prepared in MilliQ water at a concentration of $26.7 \mathrm{mg} / \mathrm{mL}$. Then, the $\mathrm{Cu}(\mathrm{II})-\mathrm{TBTA}$ complex was prepared by mixing $50 \mu \mathrm{L}$ TBTA solution and $50 \mu \mathrm{L} \mathrm{CuSO}_{4}$ stock solution. The mixture was vortexed to ensure homogeneous mixing. Separately, NB-PEG-alkyne $(290 \mathrm{mg}, 76 \mu \mathrm{mol})$ and 6-SA-Lac-N $3(56.8 \mathrm{mg}$, $84 \mu \mathrm{mol})$ was dissolved in $4 \mathrm{~mL}$ of DMF/water mixture $(1: 1 \mathrm{v} / \mathrm{v})$. Then $100 \mu \mathrm{L}$ of $\mathrm{Cu}(\mathrm{II})-\mathrm{TBTA}$ complex ( 0.1 equiv. to azide) was added via a syringe, and the resulting solution was degassed by sparging with nitrogen gas. The reaction was initiated by injecting $100 \mu \mathrm{L}$ of freshly prepared sodium ascorbate solution $(66.2 \mathrm{mg} / \mathrm{mL}$ in water, 0.4 equiv. to azide), and the color of mixture immediately turned light yellow. The reaction was stirred at room temperature overnight to maximize conversion. The reaction mixture was filtered through a $0.45 \mu \mathrm{m}$ PTFE filter and purified by preparatory HPLC using a gradient of $10-60 \% \mathrm{MeCN}$ in water with $0.1 \%$ acetic acid over $30 \mathrm{~min}$. The combined pure fractions were neutralized to $\mathrm{pH} 6.5$, concentrated under vacuum, dialyzed against MilliQ water (MWCO $3500 \mathrm{Da}$ ) and finally freeze-dried to give a white powder (247 mg, yield $72 \%)$.

${ }^{1} \mathrm{H}$ NMR (300 MHz, $\left.\mathrm{D}_{2} \mathrm{O}\right): 8.08$ (s, 1H), 6.37 (s, 2H), 5.74 (d, 1H, $\left.J=9.0 \mathrm{~Hz}\right), 4.48$ (d, 1H, J= $\left.7.8 \mathrm{~Hz}\right)$, $4.24(\mathrm{~m}, 2 \mathrm{H}), 4.10-3.51(\mathrm{~m}, 371 \mathrm{H}), 3.44(\mathrm{~m}, 4 \mathrm{H}), 3.24(\mathrm{~s}, 2 \mathrm{H}), 3.08(\mathrm{t}, 2 \mathrm{H}, J=6.9 \mathrm{~Hz}), 2.91(\mathrm{~s}, 2 \mathrm{H})$, $2.84(\mathrm{t}, 2 \mathrm{H}, J=6.9 \mathrm{~Hz}), 2.72(\mathrm{dd}, 1 \mathrm{H}, J=4.8 \mathrm{~Hz}$ and $12.3 \mathrm{~Hz}), 2.01(\mathrm{~s}, 3 \mathrm{H}), 1.75(\mathrm{t}, 1 \mathrm{H}, J=12.3 \mathrm{~Hz})$, $1.59(\mathrm{~d}, 1 \mathrm{H}, J=9.9 \mathrm{~Hz}), 1.51(\mathrm{~d}, 1 \mathrm{H}, J=9.9 \mathrm{~Hz})$.

The structure was also confirmed by MALDI-TOF MS (Figure S4).

\section{Synthesis of NB-OEG3-OH}

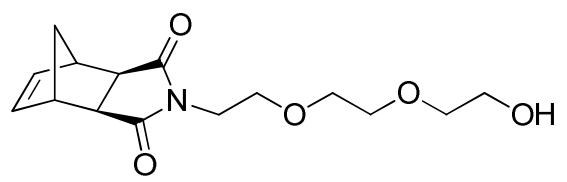

A round bottom flask was charged with cis-5-norbornene-exo-2,3-dicarboxylic anhydride (0.95 g, 5.80 mmol), 2-(2-(2-aminoethoxy)ethoxy)ethanol $(0.95 \mathrm{~g}, 6.28 \mathrm{mmol})$, triethylamine $(80 \mu \mathrm{L}, 0.58 \mathrm{mmol})$ and toluene $(20 \mathrm{~mL})$. After the reaction was refluxed at $140{ }^{\circ} \mathrm{C}$ overnight with a Dean-Stark apparatus, the reaction was cooled to room temperature, and the solvent was removed under vacuum. The residue was dissolved in $30 \mathrm{~mL}$ of DCM, washed with $0.1 \mathrm{M} \mathrm{HCl}$ (a.q.), and washed with brine. The organic phase was dried over $\mathrm{Na}_{2} \mathrm{SO}_{4}$ and concentrated in vacuo to give a slightly yellow viscous oil (1.63 g, yield 95\%).

${ }^{1} \mathrm{H}$ NMR $\left(300 \mathrm{MHz}, \mathrm{CDCl}_{3}\right): \delta 6.28(\mathrm{t}, 2 \mathrm{H}, J=1.8 \mathrm{~Hz}), 3.76-3.50(\mathrm{~m}, 12 \mathrm{H}), 3.30-3.23(\mathrm{~m}, 2 \mathrm{H}), 2.69$ $(\mathrm{d}, 2 \mathrm{H}, J=1.4 \mathrm{~Hz}), 1.66$ (br), 1.49 (d, $1 \mathrm{H}, J=9.9 \mathrm{~Hz}), 1.35(\mathrm{~d}, 1 \mathrm{H}, J=9.9 \mathrm{~Hz})$.

LRMS (ESI) m/z calculated for $\mathrm{C}_{20} \mathrm{H}_{26} \mathrm{NO}_{6}[\mathrm{M}+\mathrm{H}]^{+}$296.1, found 296.1.

\section{Synthesis of NB-OEG3-AK}




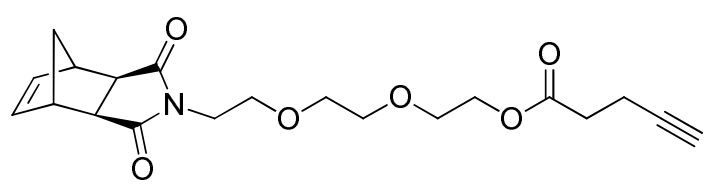

NB-OEG3-OH (738 mg, $2.5 \mathrm{mmol})$, pentynoic acid (250 mg, $2.5 \mathrm{mmol})$, and DMAP (100 mg, $0.82 \mathrm{mmol})$ were dissolved in $15 \mathrm{~mL}$ of dichloromethane. $\mathrm{EDC} \cdot \mathrm{HCl}(580 \mathrm{mg}, 3.0 \mathrm{mmol})$ was then added to the solution, and the reaction was stirred at room temperature overnight. After solvent was evaporated under vacuum, the reaction mixture was redissolved in $20 \mathrm{~mL}$ DCM, washed with water and purified over silica gel column chromatography using EtOAc/hexanes (3:1, v/v) to afford a slightly yellow viscous oil (577 $\mathrm{mg}$, yield $62 \%, R_{f}=0.58$ ).

${ }^{1} \mathrm{H}$ NMR $\left(300 \mathrm{MHz}, \mathrm{CDCl}_{3}\right): \delta 6.27(\mathrm{t}, 2 \mathrm{H}, J=1.8 \mathrm{~Hz}), 4.30-4.14(\mathrm{~m}, 2 \mathrm{H}), 3.73-3.61(\mathrm{~m}, 6 \mathrm{H}), 3.60-$ $3.54(\mathrm{~m}, 4 \mathrm{H}), 3.27-3.24(\mathrm{~m}, 2 \mathrm{H}), 3.31-3.20(\mathrm{~m}, 2 \mathrm{H}), 2.67(\mathrm{~d}, 2 \mathrm{H}, J=1.2 \mathrm{~Hz}), 2.61-2.53(\mathrm{~m}, 2 \mathrm{H})$, $2.53-2.45(\mathrm{~m}, 2 \mathrm{H}), 1.97(\mathrm{t}, 1 \mathrm{H}, J=2.6 \mathrm{~Hz}), 1.47(\mathrm{~d}, 1 \mathrm{H}, J=9.9 \mathrm{~Hz}), 1.35(\mathrm{~d}, 1 \mathrm{H}, J=9.9 \mathrm{~Hz})$.

LRMS (ESI) $\mathrm{m} / \mathrm{z}$ calculated for $\mathrm{C}_{20} \mathrm{H}_{26} \mathrm{NO}_{6}[\mathrm{M}+\mathrm{H}]^{+}$376.2, found 376.2.

\section{Synthesis of NB-OEG3-SA}

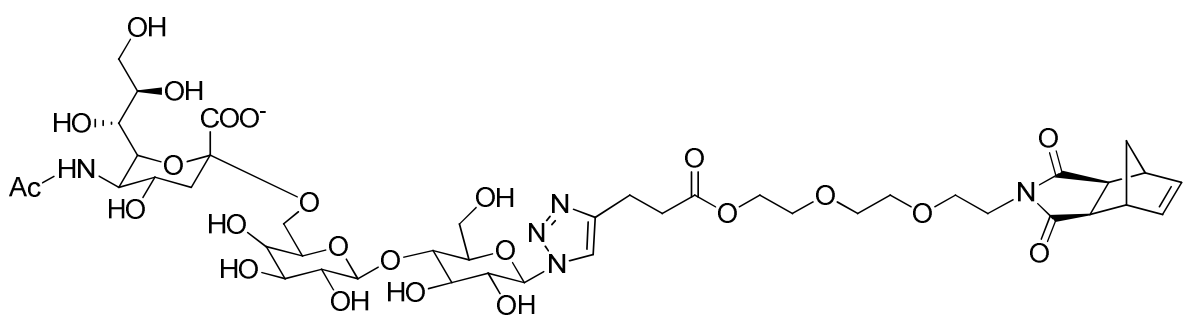

The synthesis was performed using a similar method as the compound NB-PEG-SA, and the reaction was monitored by LC-MS to ensure $>90 \%$ conversion. The reaction mixture was purified by preparatory HPLC using a gradient of 5-60\% MeCN in water with $0.1 \%$ acetic acid over $20 \mathrm{~min}$. The combined pure fractions were neutralized to $\mathrm{pH} 6.5$, mixed with $60 \mathrm{mg}$ of metal scavenger (Ethylenediaminetriacetic acid acetamide, polymer-bound, \#656844, Aldrich, 20 equiv. relative to the original amount of $\mathrm{CuSO}_{4}$ in reactant mixture) and stirred overnight to remove residual $\mathrm{Cu}^{2+}$. The beads were filtered, and the filtrate was dialyzed against MilliQ water (MWCO $500 \mathrm{Da}$ ) and finally freeze-dried to give a white powder (yield 60\%).

${ }^{1} \mathrm{H}$ NMR (300 MHz, $\left.\mathrm{D}_{2} \mathrm{O}\right): 8.06(\mathrm{~s}, 1 \mathrm{H}), 6.31(\mathrm{~s}, 2 \mathrm{H}), 5.73(\mathrm{~d}, 1 \mathrm{H}, J=9.3 \mathrm{~Hz}), 4.47$ (d, 1H, $\left.J=7.8 \mathrm{~Hz}\right)$, $4.21(\mathrm{~s}, 2 \mathrm{H}), 4.11-3.47(\mathrm{~m}, 31 \mathrm{H}), 3.17(\mathrm{~s}, 2 \mathrm{H}), 3.06(\mathrm{t}, 2 \mathrm{H}, J=6.9 \mathrm{~Hz}), 2.87-2.76(\mathrm{~m}, 4 \mathrm{H}), 2.70(\mathrm{dd}$, $1 \mathrm{H}, J=4.5 \mathrm{~Hz}$ and $12.0 \mathrm{~Hz}), 2.00(\mathrm{~s}, 3 \mathrm{H}), 1.75(\mathrm{t}, 1 \mathrm{H}, J=12.0 \mathrm{~Hz}), 1.45(\mathrm{~d}, 1 \mathrm{H}, J=9.9 \mathrm{~Hz}), 1.27(\mathrm{~d}, 1 \mathrm{H}$, $J=9.9 \mathrm{~Hz})$.

LRMS (ESI) m/z calculated for $\mathrm{C}_{43} \mathrm{H}_{62} \mathrm{~N}_{5} \mathrm{O}_{24}[\mathrm{M}-\mathrm{Na}]^{-}$1032.4, found 1032.4.

\section{S9. Additional Supporting Figures}

\section{A. GPC}




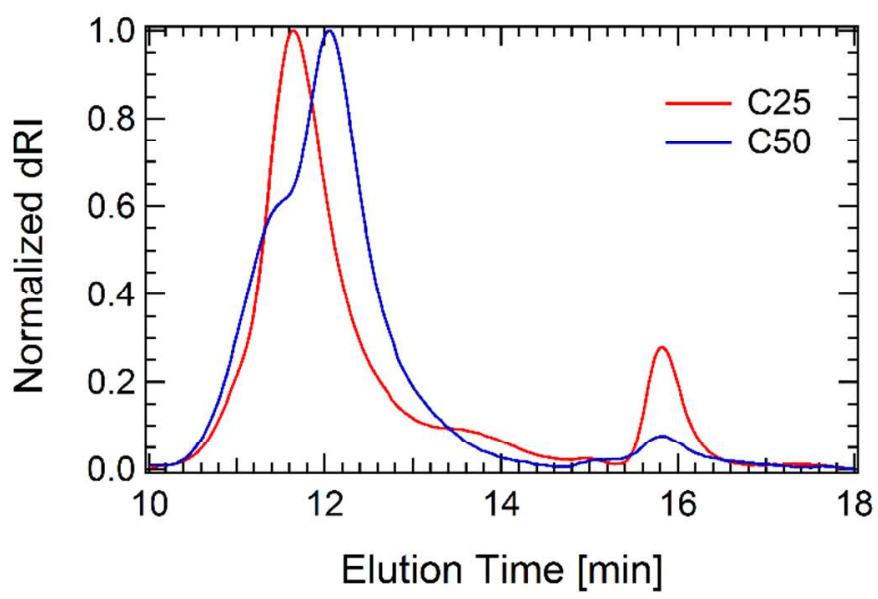

Figure S9. GPC traces of brush copolymers C25 and C50 (crude polymerization mixture). Relative poor control over the molecular weight distribution is attributed to rapid gelation during polymerization.

\section{B. NMR spectra}
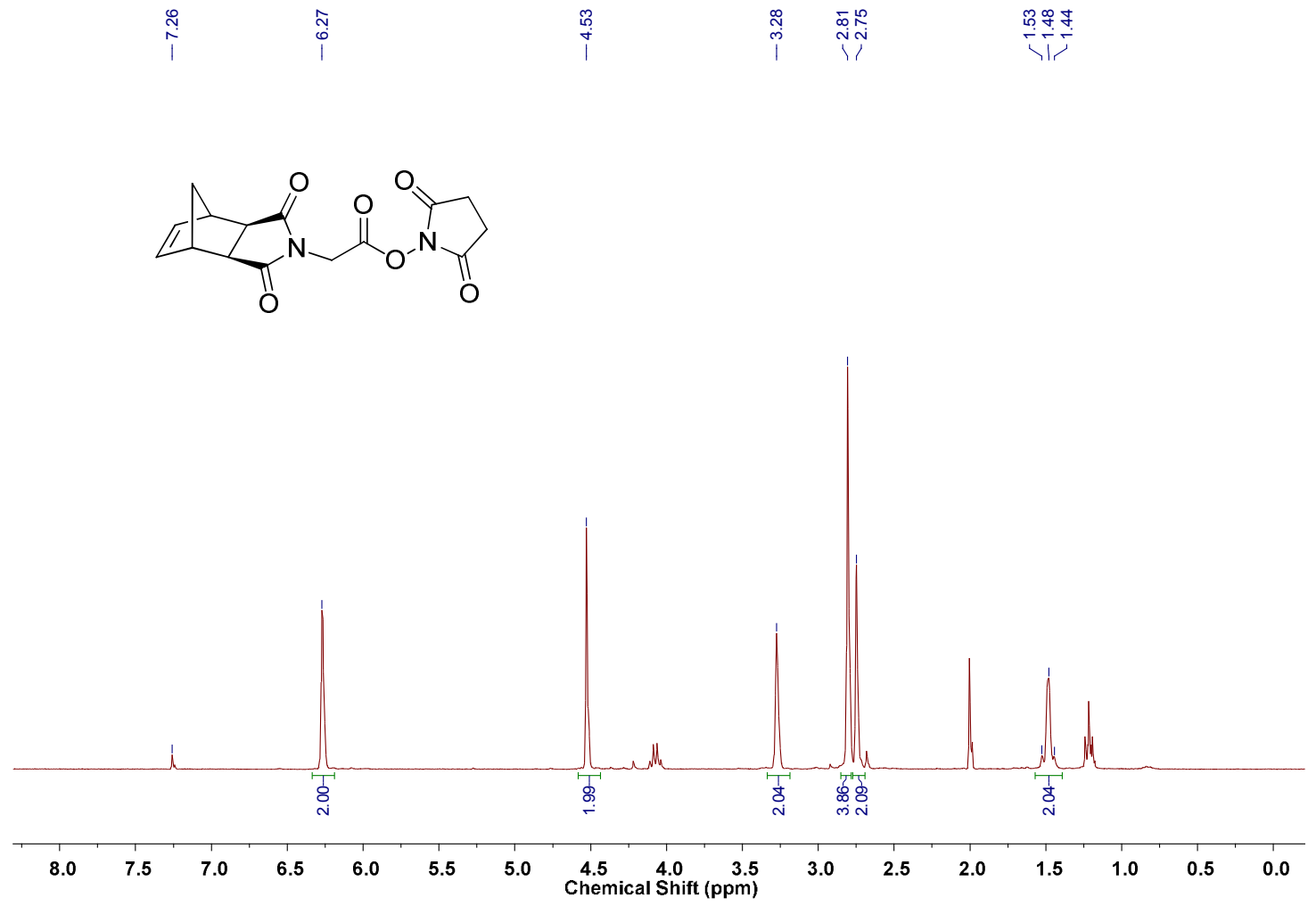

Figure S10. ${ }^{1} \mathrm{H}$ NMR spectrum of NB-NHS in $\mathrm{CDCl}_{3}(300 \mathrm{MHz})$. 


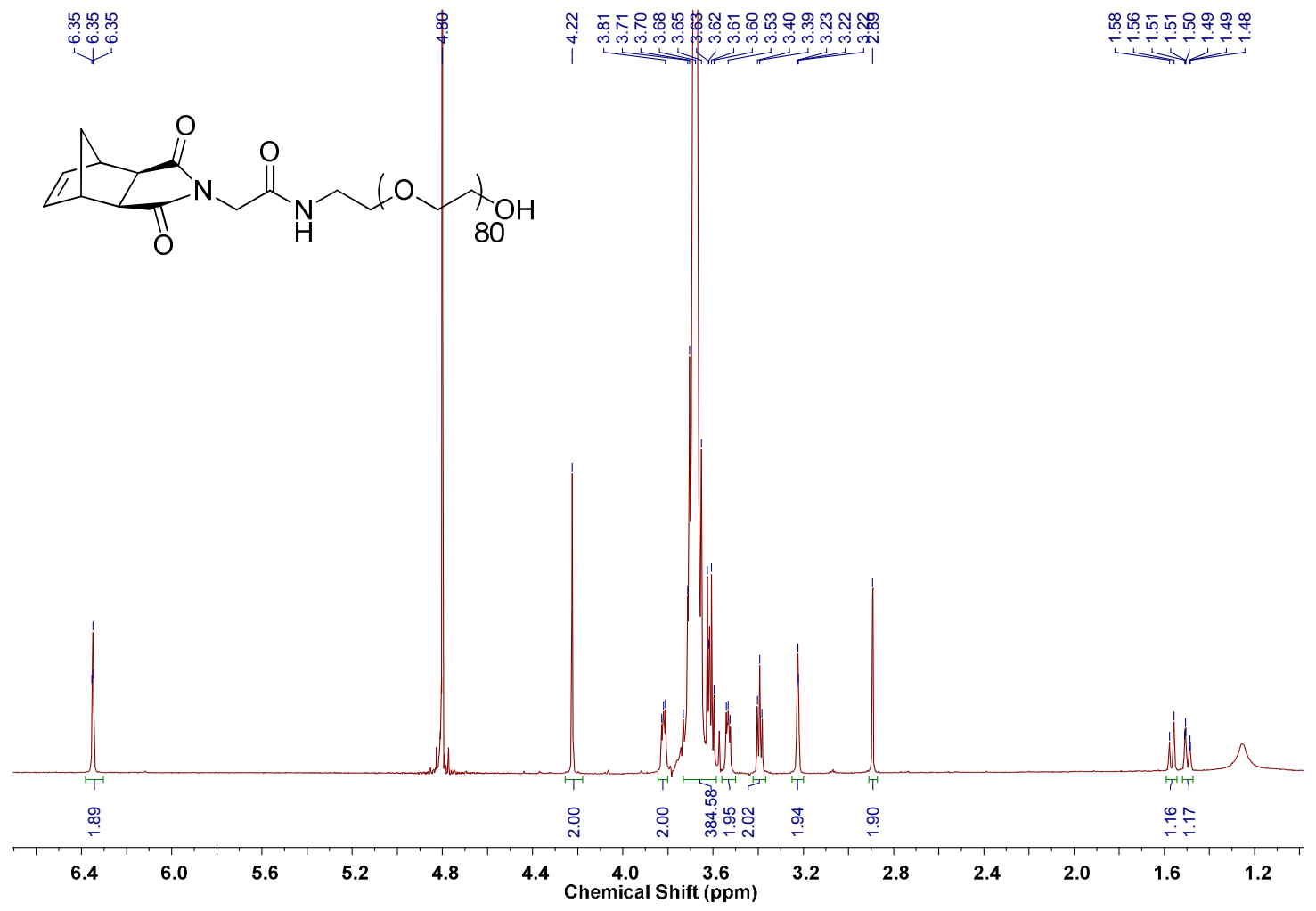

Figure S11. ${ }^{1} \mathrm{H}$ NMR spectrum of NB-PEG-OH in $\mathrm{D}_{2} \mathrm{O}(500 \mathrm{MHz})$.

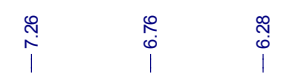<smiles>C#CCCC(=O)OC(C)COC(C)CNC(=O)CN1C(=O)C2C3C=CC(C3)C2C1=O</smiles>
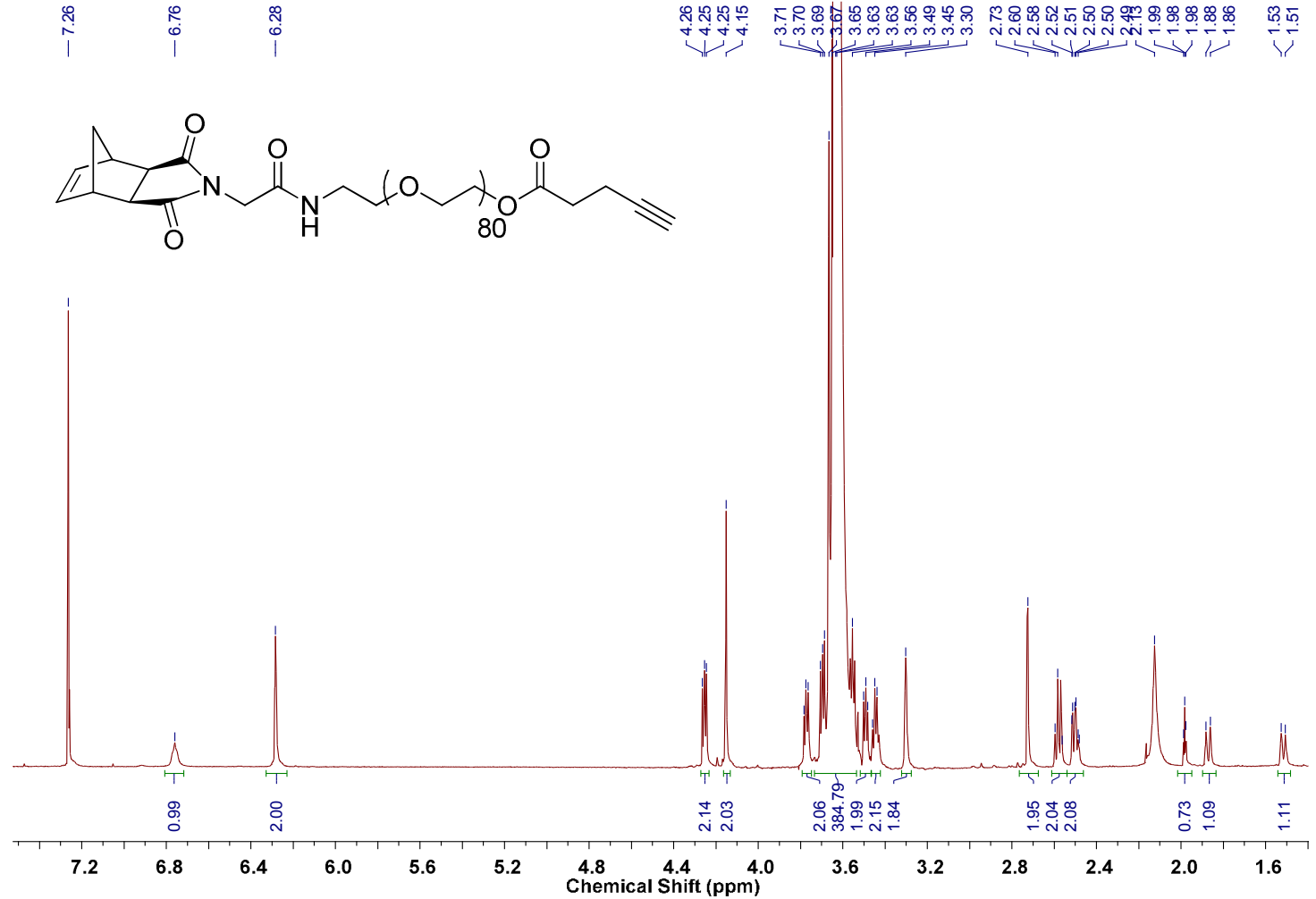

Figure S12. ${ }^{1} \mathrm{H}$ NMR $(300 \mathrm{MHz})$ spectrum of NB-PEG-AK in $\mathrm{CDCl}_{3}$. 


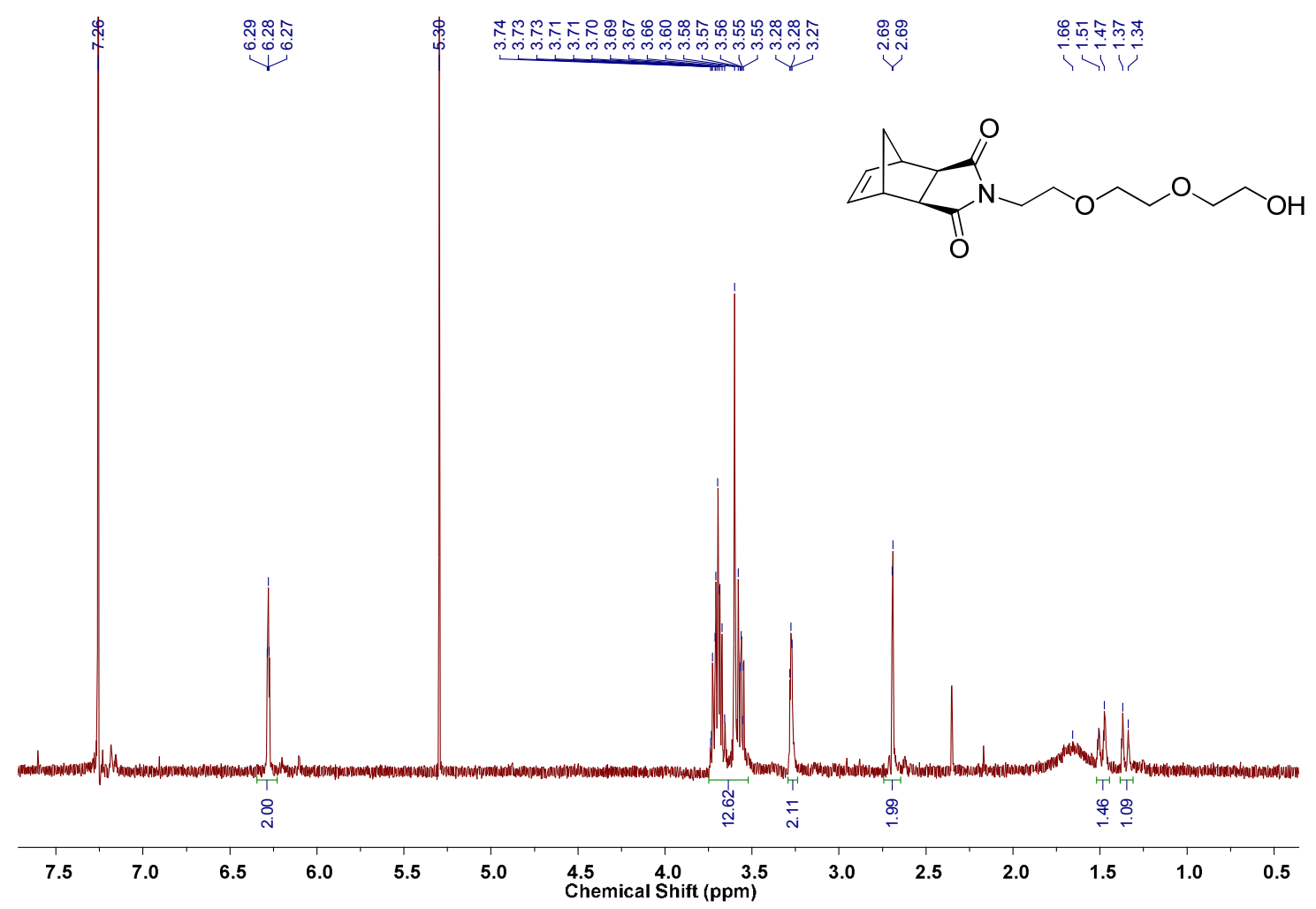

Figure S13. ${ }^{1} \mathrm{H}$ NMR spectrum of NB-OEG3-OH in $\mathrm{CDCl}_{3}(300 \mathrm{MHz})$.

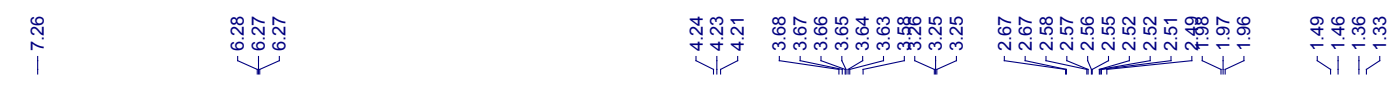<smiles>C#CCCC(=O)OCCOCCOCCN1C(=O)C2C3C=CC(C3)C2C1=O</smiles>

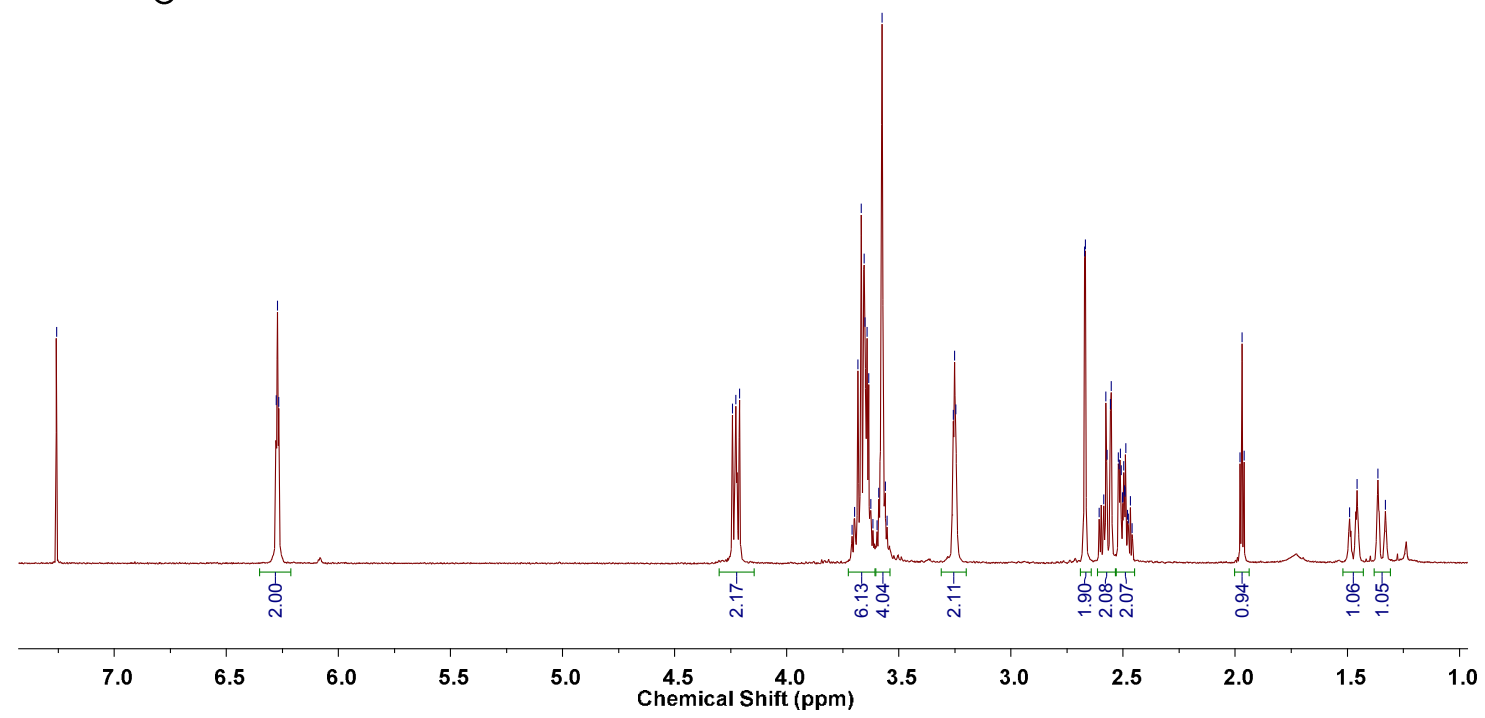

Figure S14. ${ }^{1} \mathrm{H}$ NMR (300 MHz) spectrum of NB-OEG3-AK in $\mathrm{CDCl}_{3}$. 


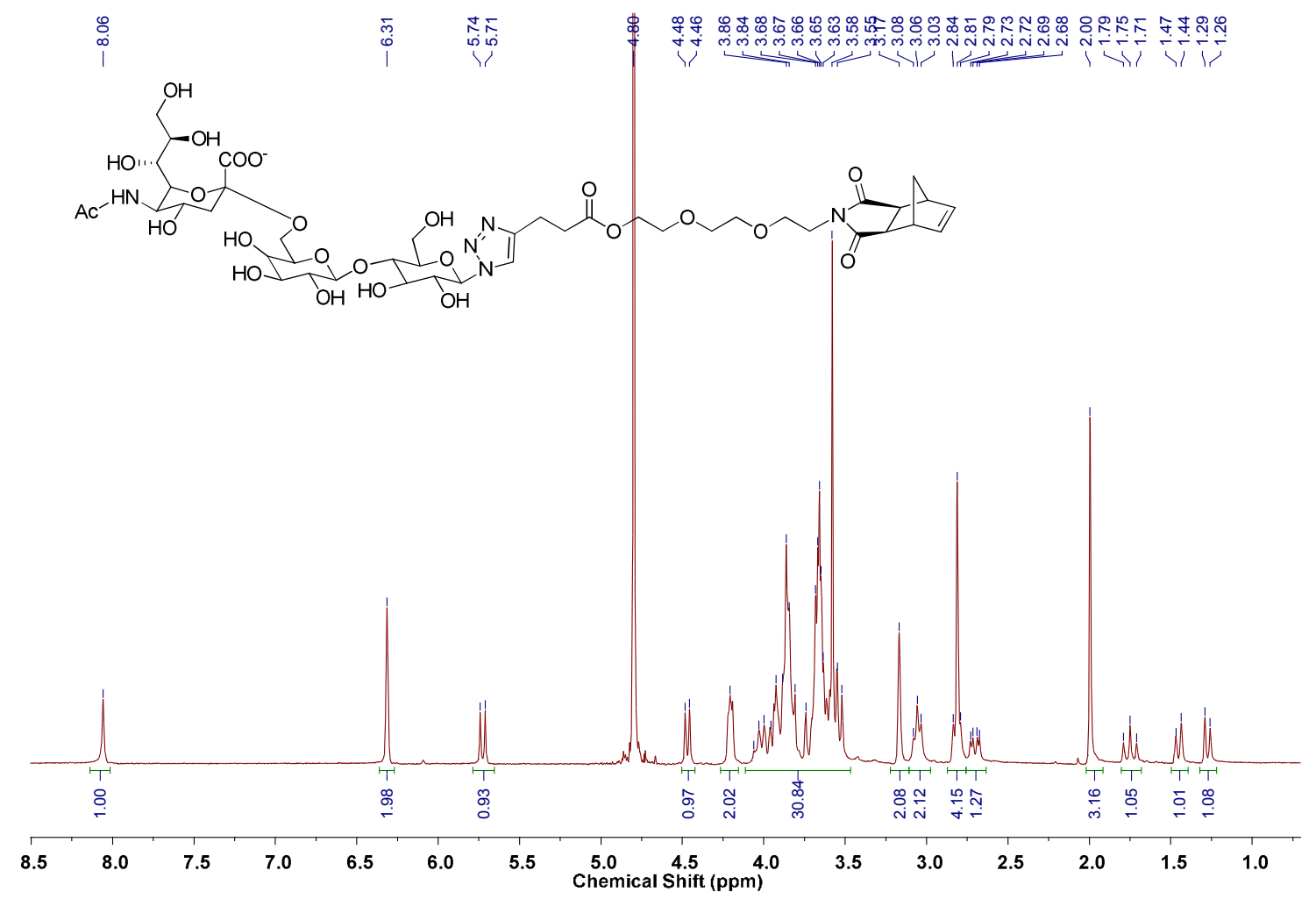

Figure S15. ${ }^{1} \mathrm{H}$ NMR spectrum of NB-OEG3-SA in $\mathrm{D}_{2} \mathrm{O}(300 \mathrm{MHz})$.

\section{MALDI-TOF MS}

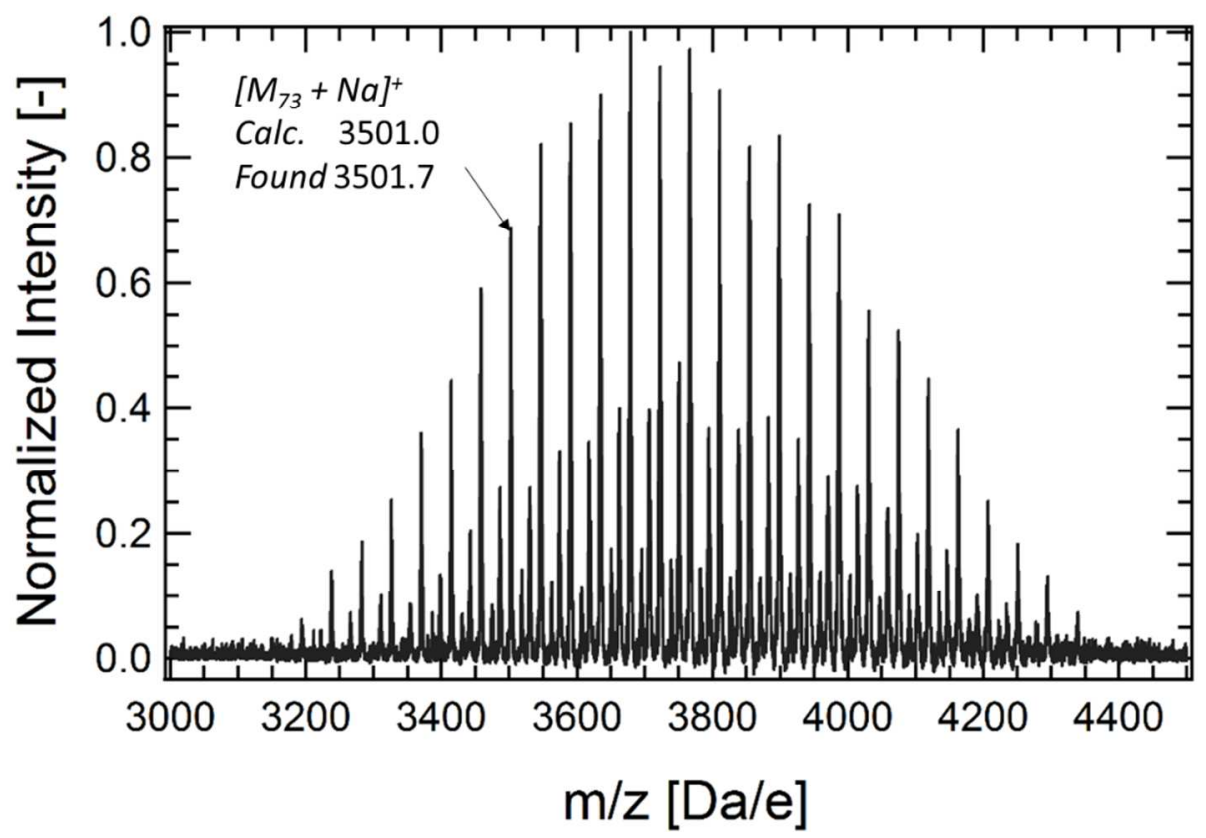

Figure S16. MALDI-TOF MS of NB-PEG-OH (positive reflector mode). 


\section{S10. References:}

1. Hill, H. D.; Reynolds, J. A.; Hill, R. L., Journal of Biological Chemistry 1977, 252 (11), 3791-8.

2. Tettamanti, G.; Pigman, W., Archives of Biochemistry and Biophysics 1968, 124, 41-50.

3. Matson, J. B.; Grubbs, R. H., Journal of the American Chemical Society 2008, 130 (21), 67316733.

4. Conrad, R. M.; Grubbs, R. H., Angewandte Chemie International Edition 2009, 48 (44), 83288330 .

5. Love, J. A.; Morgan, J. P.; Trnka, T. M.; Grubbs, R. H., Angewandte Chemie International Edition 2002, 41 (21), 4035-4037.

6. $\quad$ Yao, K.; Ubuka, T.; Masuoka, N.; Kinuta, M.; Ikeda, T., Analytical Biochemistry 1989, 179 (2), 332-335.

7. Tanaka, T.; Nagai, H.; Noguchi, M.; Kobayashi, A.; Shoda, S.-i., Chemical Communications 2009, (23), 3378-3379.

8. Vinson, N.; Gou, Y.; Becer, C. R.; Haddleton, D. M.; Gibson, M. I., Polymer Chemistry 2011, 2 (1), 107-113.

9. Tanaka, T.; Ishitani, H.; Miura, Y.; Oishi, K.; Takahashi, T.; Suzuki, T.; Shoda, S.-i.; Kimura, Y., ACS Macro Letters 2014, 3 (10), 1074-1078. 